\title{
Return Migration, Crime, and Electoral Engagement in Mexico
}

\author{
Christian Ambrosius (christian.ambrosius@fu-berlin.de) \\ UNAM and Free University of Berlin \\ Covadonga Meseguer (covadonga.meseguer@gmail.com) \\ LSE and Comillas University, ICADE-ICAI
}

This version accepted for publication in Electoral Studies $\mathbf{2 8}^{\text {th }}$ April 2020 


\section{Introduction}

In recent years, a net migration rate close to zero between the United States (U.S.) and Mexico has made headlines (Passel, Cohn, and Gonzalez-Barrera 2012). Several factors have contributed to this dramatic change in migration patterns: following the tightening of migration restrictions in the north and changing demographic trends in Mexico, emigration rates have fallen considerably. At the same time, the Great Recession in the U.S. has sent many Mexican migrants back home and deterred many others from undertaking the journey to the U.S. While the literature exploring the political consequences of emigration in sending countries is booming, hardly any research exists on what the return of migrants "with augmented human capital, financial capital (savings), foreign connections, ideas, and, perhaps critically, changed expectations" (Kapur 2014, 486) may imply for the outlook of new democracies. We start to unpack this black box by studying the impact of return migration on electoral participation.

Limited scholarly research has shown that return migrants, especially returnees coming back from advanced polities, may be drivers of democratic change by disseminating their views about democratic governance and political accountability learned abroad (Levitt 1998; Pérez-Armendáriz and Crow 2010; Chauvet and Mercier 2014; Batista and Vicente 2011; Tuccio, Wahba, and Hamdouch 2019). However, some authors remain sceptical about the long-lasting effect of returnees in enhancing the democratic life of the localities to which they return (Pérez-Armendáriz 2014). Research on Mexico has shown that returnees tend to disengage from politics shortly after their arrival, in part as a reaction to the ill-will of non-migrant co-nationals, who find returnees too "dissimilar" to be valuable role models (Fitzgerald 2013; PérezArmendáriz 2014, 82). In this paper, we offer a systematic test of these alternative views by looking at electoral turnout in presidential elections in Mexico. 
The increasing flows of return migrants have taken place against a worsening of the security situation, particularly after 2006. According to theories of return migration, the impact that returnees may have in their communities is, among other factors, contingent on the context they encounter upon return (Cassarino 2004, 257). Several authors have reported a negative effect of high levels of homicide rates and organised violence by criminal organisations on the likelihood of showing up to vote on election day (Trelles and Carreras 2012a; Ley 2018). We argue that some of the mechanisms by which return migration may enhance political engagement are less likely to play out in the context of low confidence in a state incapable of protecting its citizens. We exploit the heterogeneity in crime rates and incidence of drugrelated violence to explore the impact that this violent context may have had on returnees' and non-migrant co-nationals' propensity to vote.

We deepen and expand recent research (Duquette-Rury and Chen 2018) by using data on local electoral participation in presidential elections over the period 2000-2012. Our research shows that electoral turnout in municipalities with high rates of return migration is, on average, lower. Moreover, the negative effect of return migration on electoral participation is exacerbated in settings where crime is rampant. This suggests that returnees' electoral alienation is shaped in part by the context of insecurity they encounter in the communities they return to. Our work contributes to an incipient research agenda on the political impact of return migration, the evolution of transnational political engagement in so-called violent democracies (Pérez-Armendáriz 2019), and the broader debate on the role of migrants as agents of democratic deepening.

On methodological grounds, our research faces the challenge that return migration is endogenous to election outcomes, leading to biased estimates. On the one hand, politics might drive migration decisions, provoking selection bias among the migrant population. On the other hand, economics drives both politics and migration, potentially causing omitted variable bias. We therefore implement an instrumental variable strategy in which we explain the rates of return migration at the municipal level as resulting from 
exogenous U.S. labour market shocks in a first step, and then use predicted rates of return migration to explain voter turnout in a second step.

The paper proceeds as follows: in the first section, we describe the changing context of return migration during this period. Next, we discuss the literature on return migration and politics, showing the existence of a large gap when it comes to understanding the impact of return migration on political behaviour. We propose several mechanisms by which rates of return migration may affect electoral participation and establish how these mechanisms may impact returnees' and non-migrant co-nationals' propensity to vote. In the third section, we discuss our data and methods. In Section Four we present the results. Finally, we conclude in Section Five with reflections and suggestions for future research.

\section{The Changing Character and Context of Return Migration}

During our period of study (2000-2012), there have been several forces affecting migration flows that we need to consider. Lower fertility rates, a major economic recession in the U.S., and a tightening of border policies have had a substantial effect on economic migration from Mexico to the U.S. (Passel, Cohn, and Gonzalez-Barrera 2012, 6; Masferrer and Roberts 2012, 466). The other major societal and political change that took place over our period of research was a dramatic worsening of the security situation (Pansters 2018). We argue that these two phenomena have caused a negative selection in return migration and a challenging context in home communities for returnees to exert an efficacious role as agents of democratic change.

Return migration figures, while patchy and scattered, give an unequivocal picture of increasing return migration flows. The 2010 Mexican census shows that the absolute number of individuals whose residence in 2005 was in the U.S. increased threefold between those two years (Masferrer and Roberts 2012, 473; Montoya-Ortiz and González-Becerril 2015). To give a sense of the magnitude of the return, in terms of proportions, "the 2010 census showed that nearly one in three $(31 \%)$ of those who had left for the 
U.S. within the previous five years had returned. That compares with about one in six (17\%) for those who had left for the U.S. within the five years prior to the 2000 Mexican census" (Passel, Cohn, and GonzalezBarrera 2012, 15). The Centre for Migratory Studies at the National Institute of Migration reports a constant return of Mexican migrants estimated at 400 thousand migrants annually (García-Zamora 2014, 41). It is not surprising that net migration figures have been close to zero in recent times (BBVA Bancomer 2015).

Regarding the characteristics of migrants and their selectivity into return migration, it is frequently mentioned that a majority of Mexican returnees came back voluntarily (Moctezuma 2013, 153). Between 2005 and 2010, the percentage of returnees who were voluntary, often moving back with their families, varied between 65\% and 95\% (Passel et al. 2012 citing Pew Hispanic research, 22). However, as the broad range of these estimates suggests, judging the voluntary character of return is often problematic (Hazan $2014,5)^{1}$ : describing as voluntary returns that very often are motivated by "limited opportunities for school or work, (...) chronic anxiety, or (...) a family member's deportation" may indeed be a stretch (Silver 2018, 209). Also, in this period, deportations have taken place in record numbers. According to Denier and Masferrer (2019), and citing data from the Department of Homeland Security (DHS), around 1.5 million Mexican nationals were removed during the Bush administration (2000-2008) and close to 2 million were deported during the Obama administration (2009-2016). Montoya-Ortiz and GonzálezBecerril $(2015,64)$ report that between 2005 and 2010, deportees amounted to $11 \%$ of total returns. ${ }^{2}$

\footnotetext{
${ }^{1}$ https://ccis.uscd.edu/_files/wp193.pdf (accessed 25 April, 2019)
}

2 Citing Cantor (2014), "Nuevo estudio revela causas de migración de retorno a México." http://immigrationimpact.com/2014/01/15/nuevo-estudio-revela-causas-de-migracion-de-retorno-a-mexico/ (accessed 30 May, 2019). 
The demographic profile of recent Mexican returnees has changed, with a predominance of married male young adults with elementary education levels and coming from rural areas rather than the well-off, highly educated retiree immigrants that characterised return migration in the past. Returnees are going back to states that historically had high levels of migration. Up to $80 \%$ return to their states of origin (Moctezuma 2013; López 2018, 23). ${ }^{3}$ And while most of these returnees find formal employment relatively quickly after they return, a majority of these, in turn, end up in low-paid jobs, disproportionally in the agricultural sector (Li Ng, Salgado, and Serrano 2016; Hazan 2014). Compared to previous decades, returnees had become less positively selected in terms of education and wages in 2010 (Campos-Vazquez and Lara 2012). Returnees' engagement in entrepreneurial activities is also less than in the past (Denier and Masferrer 2019; Parrado and Gutiérrez 2016).

Changing political and economic circumstances in the U.S. hit immigrants who were in a more vulnerable position badly: undocumented migrants and those with shorter stays in the U.S, who lacked solid networks to rely on (Hazan 2014, 17). As Hazan (2014) found in her study on return migration in Jalisco, the tightening of enforcement and immigration policies together with an acute economic recession in the U.S. "[broke] families apart, weakened social safety nets, expanded the sense of nostalgia and homesickness, and increased the obstacles for migrants to find jobs in an already difficult economic scenario." 4 The non-voluntary character (whether forcible or not) of return meant that returnees were unprepared to make the move. Under these circumstances, returnees' capacity to mobilise the savings,

\footnotetext{
${ }^{3}$ Masferrer and Roberts $(2012,469-70)$ find that return to places other than those of birth was estimated as making up a quarter of returns.
}

${ }^{4}$ Her study is based on a survey of 601 return migrants to Jalisco. The survey was carried out between 2 May and 6 June, 2013. 
contacts, and experience necessary to exert an impact in their communities of origin may have been limited (Cassarino 2004; Masferrer and Roberts 2012; Parrado and Gutiérrez 2016; Denier and Masferrer 2019).

Concerning the context returnees encountered upon return, prominently after 2006, Mexico became the epitome of a violent democracy; that is, a governing system "in which competitive elections, civil freedoms, and inclusive participation have taken root yet the state does not control sub-state violence" (Pérez-Armendáriz 2019, 2). Although violence in Mexico has deep historical roots that reach back far beyond the most recent wave of drug-related criminality (Pansters 2018), we focus on the escalation of violence during Felipe Calderón’s administration (2006-2012). Mexican cartels have been active in trafficking marijuana and poppy for over a century. Several cartels have dominated the criminal scene; the Tijuana, Juárez, Sinaloa, and Gulf cartels. These cartels co-existed relatively peacefully, but by the mid1990s, processes of subnational democratisation and the transition to a multiparty democracy had left the cartels on their own in terms of regulating the drug industry. Lacking the government protection they had previously enjoyed, the cartels went to war, resulting in a dramatic escalation of drug-related crimes (Meseguer, Ley, and Ibarra-Olivo 2017, 2173-4; Trejo and Ley 2018; Shirk and Wallman 2015; Pansters 2018; Rios 2015). When Calderón took office following a contested election, he made the fight against drug violence the cornerstone of his mandate. Calderón decided to fight organised crime by militarising the conflict, capturing and killing the leaders of these organisations. The side effect of this strategy was a worsening of the situation as cartels fought internally and between each other to control the industry and defend their territories. The number of different cartels rose, causing generalised violence at the local level (Shirk and Wallman 2015; Guerrero 2010; Calderón et al. 2015).

Importantly, the wave of return migration we look at took place against the background of the failed migration strategy under the two subsequent PAN (Partido de Acción Nacional) presidencies. Vicente Fox (2000-2006) started his mandate with high ambitions of reaching a grand bilateral agreement with 
Mexico's northern neighbour. ${ }^{5}$ However, negotiations came to a halt in 2001 following the September 11 events. Despite multiple initiatives to reach out and engage Mexicans abroad, ${ }^{6}$ the criminalisation of migration and the adoption of highly restrictive policies in the U.S. increased the perception that Fox's administration failed to enhance the status and rights of Mexican migrants. While U.S. discourse on migration became tougher, and protests among the migrant community in the U.S. mounted, Felipe Calderón (2006-2012) pushed migration downward in the bilateral agenda to prioritise the fight against criminal organisations. During his presidency, when migration entered the political scene, it was frequently linked to a deteriorating security situation. Paradoxically, irregular migrants were often portrayed as the main threat to border security, while in parallel they became frequent targets and victims of criminal organisations in their journeys to the U.S. (Orozco-Aleman and Gonzalez-Lozano 2018, 718). As Durand put it, "the general perception is that President Calderón abandoned migrants" $(2013,767) .{ }^{7}$ Felipe Calderón's party lost the 2012 presidential election to the opposition candidate, Enrique Peña Nieto (Partido Revolucionario Institucional).

5 The "whole enchilada", as it was popularly referred to in the media, included among other measures a process for regularization of migrants in the U.S., a new temporary worker agreement, better border security, and development initiatives in out-migration areas (Délano 2012, 45).

${ }^{6}$ Probably the most remarkable development in this regard was the recognition of voting rights for emigrants in the 2006 federal election for the first time. However, participation was extremely low. Scholars attribute this fact to high bureaucratic barriers to casting a vote, low political engagement prior to departure, relatively short stays in the destination, low socioeconomic status, and lack of solid social networks while abroad. All these factors negatively affect migrants' capacity to acquire new political capital that can subsequently be imported (Waldinger and Soehl 2013; Wals 2013; McCann, Cornelius, and Leal 2009).

${ }^{7}$ Authors' translation. 
Given these parallel demographic, societal, and political dynamics, the lack of research exploring how increasing return flows to violent settings might have affected electoral engagement is surprising. Because of the centrality and the visibility of the Mexican president in the design of migratory and security policies, and in Mexican politics in general, we consider it vital to study the effect of return migration on electoral participation in presidential elections. ${ }^{8}$

\section{Return Migration and Political Engagement in a Violent Democracy}

Research on the political consequences of international migration for sending countries is rapidly expanding (Kapur 2010, 2014). The question motivating this growing research agenda is: Do migrants remit democratic practices (Pérez-Armendáriz and Crow 2010; Pfutze 2012)? Several results seem robust. Émigrés transmit democratic values and practices, but apparently only if they settle down in countries with good governance and working democratic institutions (Spilimbergo 2009; Córdova and Hiskey 2015; Maydom 2017). Exposure of those left behind to emigrants' ideas increases non-electoral political participation (Goodman and Hiskey 2008; Pérez-Armendáriz and Crow 2010; Germano 2013; Córdova and Hiskey 2015). There also seems to be evidence of attitudinal changes, such as more support for democracy in general, but a more critical stance with respect to how democracy works in the home country (Bravo 2009; Goodman and Hiskey 2008; Pérez-Armendáriz and Crow 2010; Córdova and Hiskey 2015).

While the so-called diaspora channel - that is, the influence of emigrants in home countries from abroad - is being thoroughly researched, we know very little about the impact that return migrants have on the political life of their communities following their return. We agree with Kapur and McHale (2012) in

\footnotetext{
${ }^{8}$ As a persistent feature of Mexican politics, analysts point to the relative irrelevance of political parties in

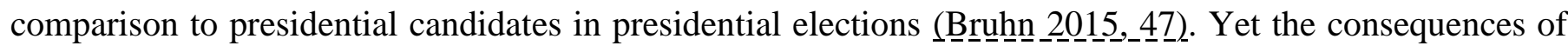
security and migration policies are most evident at the community level and therefore, for robustness, we show how return migration affects turnout in municipal elections in the Supplementary Appendix.
} 
that return migration is the least explored channel of migrants' political impact. The literature on social remittances - the "ideas, behaviours, identities, and social capital that flow from receiving to sending country communities" (Levitt, 1998: 927) - is of relevance in this exploration because returnees exert influence in their communities through the values, norms, practices, and resources they acquire abroad and bring back home with them (Levitt 1998; Pérez-Armendáriz and Crow 2010; Levitt and Lamba-Nieves 2011). ${ }^{9}$ In what follows, we distinguish the conditions that in our view affect the capacity and willingness of returnees to engage in electoral politics from those that may shape the receptivity of non-migrant conationals to returnees' social remittances. We further discuss how a context of crime may impair the diffusion of social remittances and affect electoral turnout.

The list of empirical works on the political consequences of return migration is not long. In the optimistic camp, Batista and Vicente (2011) found that a higher proportion of return migrants in Cape Verde localities increased the demands for greater accountability. Mercier and Chauvet (2014) used census data and the election results for the 2009 municipal elections in Mali and found a positive impact of returnees coming back from different destinations on turnout. Tuccio et al. (2019) show that return migration increased the demand for social and political change, as well as electoral turnout in the 2011 parliamentary elections in Morocco. In all these case studies, positive effects on accountability and turnout are associated with the presence of return migrants coming back from Western Europe (but not from other destinations), arguably having been exposed to better functioning political institutions. In Mexico, Waddell and Fontenla's (2015) study of return migration to the state of Guanajuato shows a positive effect of returnees on health, education, income, and political participation in their communities. In sum, in these

${ }^{9}$ While there is research on the economic impact that returnees have in their communities (Mercier and Chauvet 2014, 631-32) there is very little empirical evidence about the political consequences of return migration. 
studies, migrants returning from better functioning polities acquired social capital that translated into more electoral engagement in home communities.

In the pessimistic camp, studying Mexico, Pérez-Armendáriz and Crow (2010) found that returnees are not more likely than non-migrants to participate in protests, join civic organizations, or engage in nonelectoral forms of political participation. Detailed exploration of the political effects of distant contact with emigrant relatives vs. face-to-face contact with returnees from the U.S. in the Mexican context reveals a mixed picture. Based on interviews with emigrants, non-migrants, and returnees, Pérez-Armendáriz (2014) found, first, that the asymmetry of power that generates pride and admiration vanishes once the relative comes back, detracting from their power as transmitters of social remittances. Second, returnees are often perceived by non-migrants as dissimilar and disconnected from the reality to which they return (Fitzgerald 2013). Partly due to this lack of a good reception, returnees try, but soon lose their interest in driving change in their communities (Pérez-Armendáriz 2014, 78). In her detailed account, non-migrant conationals appear to be an important factor deterring returnees from exerting change in their communities. More recently, Duquette-Rury and Chen (2018) found that return migration decreased turnout in municipal elections by 4-5 percent.

Note, then, that these contradictory findings make it necessary to think systematically about the conditions under which a positive political impact of return is more likely. In our view, returning migrants must have had, first, a quality stay in the destination (in terms of time and integration in the host society) in order to learn the benefits of political participation and good governance. Once back home, returnees have to be motivated to spread their acquired social and political capital through their regular contact with nonmigrants, or by taking over leadership roles in their communities. Second, non-migrant co-nationals must be receptive to these imported social remittances. We argue that these conditions are not exclusive and that there are good reasons to argue that none of them were present in the most recent wave of return migration into Mexico. 
To begin, rather than being the end of a natural migration cycle, the return stream we explore resulted from an economic recession and the implementation of tougher immigration and border enforcement measures. As Hazan puts it, these returnees were more likely to belong to "a fairly disempowered population in the U.S." (Hazan 2014, 38-39). ${ }^{10}$ Many left the U.S. without having had the time to augment their financial resources or to integrate in the destination. For example, the returnees interviewed in Hazan's study barely participated in civic organisations or took part in Home Town Associations (HTAs) while abroad. Besides exposing them to greater vulnerability amidst increasing adverse economic conditions and anti-immigrant policies in the U.S., low levels of social connectivity in the destination implied limited opportunities for migrants to increase their social capital and learn from democratic practices in the destination (Waldinger and Soehl 2013). To a large extent, return was unprepared and unwanted, making reintegration challenging (Masferrer and Roberts 2012, 472; Parrado and Gutiérrez 2016). Consequently, the motivation to exert the role of "agents of change" through electoral engagement is likely low, especially when returnees contemplate re-emigration (Martínez, Slack, and Martinez-Schuldt 2018). Narrowed exit options may further depress the sense of belonging and moral obligation to contribute to the betterment of their communities, undermining returnees' sense of public duty. All these variables negatively affect the value attributed to the act of showing up to vote.

On the part of non-migrant co-nationals, for social remittances to spread, non-migrant co-nationals need to regard returnees as valid interlocutors and worthy role models. However, non-migrant co-nationals and families with returnees frequently find that "returnees do not adapt well to living with the family again" (Pérez-Armendáriz 2014, 82). Returnees are often a source of "more problems than benefits" (Pérez-Armendáriz 2014, 82). This in turn undermines social cohesion in their communities. Moreover, the utilitarian value of having an émigré relative abroad disappears with return (Pérez-Armendáriz 2014, 85),

10 In Hazan's study, the percentage of undocumented returnees is high: 73\% (Hazan 2014, 27) https://ccis.ucsd.edu/_files/wp193.pdf (accessed 25 April, 2019) 
the more so if the return was involuntary, with little financial resources, and under the stigma of failure. The kind of ill-will and feelings of dissimilarity returnees often encounter feeds on their perception of political efficacy and may deteriorate even further their motivation to engage in electoral politics.

How may a context of insecurity and rampant violence affect the conditions for returnees and nonmigrant co-nationals to participate in elections $?^{11}$ Scholars of Mexican politics have reported that crime has a negative impact on the confidence and support that citizens have for political systems and institutions in a context where states appear incapable of protecting their citizens. The presence of criminal organisations during elections alters the perception that individuals have of the ability of their vote to make a difference (Ley 2018, 1968). Citizens choose to retreat from the public to a "private sphere", which decreases their probability of participating in elections (Trelles and Carreras 2012a, 101). This context may certainly not be the best for social remittances brought back by returnees to kick in. In particular, we anticipate that crime and the failed political response to it, together with the criminalisation of migration, may exacerbate both returnees' unwillingness to engage in politics and non-migrants' disdain towards returnees, causing widespread political disenchantment.

On the part of returnees, research has shown that they tend to make harsher evaluations of government performance than do non-migrants (Pérez-_Armend_áriz and___ 2016.). As Jiménez reports in his research, those that have lived abroad "are far more likely to be dissatisfied with Mexican institutions" (Jiménez 2008, 29). Returning to largely faulty local polities where trust in the efficacy of political parties is low due to pervasive violence, returnees are unlikely to consider

${ }^{11}$ While some authors have shown that variables such as political alternation, federal structures, party label in power, or past history of social mobilisation has an effect on crime incidence (Trejo and Ley 2018; Ley, Mattiace, and Trejo 2019), we are not aware of any work showing that electoral turnout affects criminal violence in Mexico. 
formal political participation an effective way to keep politicians accountable. The political context described above in which migrants felt sidelined in the presidential agenda, and were frequently victimised and criminalised, must have deepened returnees' suspicion of the political class. Moreover, insecurity is a strong push factor behind emigration decisions. It makes sense to expect that migrants involuntary returning to areas "ravaged by conflict" and lacking opportunities to live safe lives will likely find

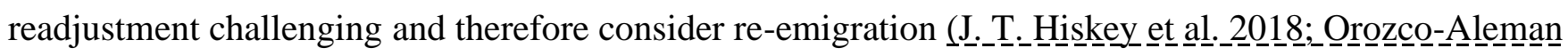
and__Gonzalez-L__ozano__2018; Sc_arnató 2019, 199). Consequently, we expect (mostly involuntary) returnees to have even less incentive to participate formally in politics in communities where violence is pervasive.

On the part of non-migrant co-nationals, the deterioration of interpersonal trust and trust in political institutions associated with a surge in crime (Trelles and Carreras 2012; Ley 2018; Blanco 2013) may increase the perception that return migrants are coming back "transformed" in a negative way, and import cultures of crime and violence (Levitt and Lamba-Nieves 2011, 19; Fitzgerald 2013). Recent returnees have often been stigmatised as "social outsiders" or, even worse, as "criminal deportees" (Silver 2018, 209; Levitt and Lamba-Nieves 2011, 19; Fitzgerald 2013, 119; Scarnato 2019). Evidence connecting crime and return migration is inconclusive, though. For instance, Bucheli et al. (2019) found that return migration may have a pacifying effect, reducing the number of homicides in Mexico, while Blake (2014) and Ambrosius and Leblang (2018) found the opposite in cross-country samples for the specific case of deported convicts. Research is too incipient to have reached a consensus on the effect of return migration on violence in origin countries. Yet the portrayal of returnees, and in particular deportees, in the media and political discourse as "presumed criminals" (Scarnato 2019, 197) may deepen non-migrant co-nationals' misgivings towards returnees, damaging local social networks, and pushing non-migrants further away from participating in elections. Note that feedback dynamics of this type imply that the impact return migration may have on electoral engagement may transcend returnees' electoral apathy. When returnees are perceived as a threat or burden, such perception may cause negative spillover effects by affecting levels of interpersonal trust and trust in political institutions (that is, communities' social capital), which in turn 
may impact electoral participation at the community level. If the impact that return migration has on turnout clearly exceeds rates of return migration, we can interpret this as evidence that spillover effects are indeed operating.

In sum, in view of the above discussion, we expect recent return migration into Mexico to be associated with a decrease in electoral engagement. Further, we expect this effect to be magnified in the presence of criminal violence. We test these propositions next.

\section{Data and Method}

We estimate the effect of return migration as captured in census data $(2000,2005$, and 2010) on electoral turnout for presidential elections in the years 2000, 2006, and 2012. For robustness, we also test the effect of return migration on turnout during municipal elections, which take place every three years in a staggered election calendar (see Supplementary Appendix Table S2). ${ }^{12}$ The main explanatory variable is return migration (Return) over the previous five years, measured as the share of population that resided in a different country five years ago. ${ }^{13}$ The fact that the average share of return migrants across all municipalities increased substantially from 2005 to 2010 (0.4\% to $1.5 \%)$ underlines the strong effect of the U.S. recession on return migration.

12 For turnout in municipal elections, we use elections held in the current census year or the most recently held election in either $t-1$ or $t-2$. Data for local elections comes from CIDAC (Centro de Investigación para el Desarrollo).

${ }^{13}$ Since turnout statistics for presidential elections are based on registered voters only, the effect of return on abstention rates should not be affected by recent returnees, who might not appear in electoral registries. For local elections (as reported in the Supplementary Appendix S2), we lack election registries and use the adult population as a second-best denominator to calculate turnout rates. 
The principal methodological challenge lies in the fact that return migration is endogenous to election outcomes, leading to biased estimates. On the one hand, politics might drive migration decisions, provoking selection bias among the migrant population. On the other hand, economics drives both politics and migration, potentially causing omitted variable bias. We therefore implement an instrumental variable strategy in which we explain the rates of return migration at the municipal level as a result of exogenous U.S. labour market shocks in a first step. We exploit variation in migrants' exposure to U.S. labour market conditions in the U.S. in the instrumental strategy. Historically, a number of different migration corridors emerged between origin regions in Mexico and destinations in the U.S. Due to network effects that reduce the costs of migration, these migration corridors exhibit strong path dependencies, and change only slowly over time (McKenzie and Rapoport 2007). For example, migration networks in the northern states date back to the recruitment of Mexican labour for railway construction in the 1920s, and later the 'bracero' program of labour recruitment in the 1950s and 1960s. In contrast, migration networks that emerged in central and southern states have a more recent origin, registering strong outward movements in the 1990s and 2000s in the context of structural changes within the Mexican agricultural sector (cp. Durand, Massey, and Parrado 1999). Different migration corridors have led to variation in exposure to U.S. labour market conditions between Mexican states, depending on the distribution of the Mexican diaspora across U.S. states. As a result, Mexican states with a larger share of migrants in U.S. states and that experienced strong increases in unemployment also received a higher influx of returning migrants.

To capture regional exposure to U.S. labour market conditions, we construct an indicator over the previous three years by subtracting the level of unemployment in U.S. state $k$ in year $t-3$ from the level of unemployment in U.S. state $k$ in year $t$. In order to generate variation by Mexican state, job creation in U.S. states is multiplied by the percentage of consular documents (matrículas consulares) that have been requested by individuals from Mexican state $j$ who lived in U.S. state $k$. Data on migration corridors comes from the cumulative number of consular documents issued by the Mexican government to nationals abroad, independently of their migration status) up to the year 2008 (Instituto de Mexicanos en el Exterior, 
IME, 2008). Note that the IME (2008) data is intentionally left without variation so that all time variation in the variable is due to fluctuations in job creation and not to changes in migration patterns. In order to obtain municipality level variation and to increase the strength of the instrument, we multiply the value of this indicator by two other variables often used as instruments in the literature (e.g., Pfutze 2012;

McKenzie and Rapoport 2007; Woodruff and Zenteno 2007; Demirgüç-Kunt et al. 2011): distance to the U.S. border along historical rail lines (distance from the municipality to the closest rail lines as they existed in 1920 and from there to the U.S. border), and the historical migration rates at the state level in the year 1924 (both variables from Demirgüç-Kunt et al. 2011). The rationale for the distance variable is that migration corridors today have their roots in the recruitment of Mexican labour along rail lines during the Bracero guest worker program (López Córdova 2005; Woodruff and Zenteno 2007). These historical roots of migration routes persist even today (Woodruff 2007; McKenzie and Rapoport 2007). For a similar reason, we give a stronger weight to unemployment shocks in states that are characterised by historically high migration rates as measured in 1924. While historical migration affects the intensity of migration rates today through path-dependencies and network effects, we do not expect these factors to affect changes in voter turnout over the years 2000 to 2012 . Note that the identification information comes from timevarying U.S. labour market shocks, whereas time-constant variables provide different weights to unemployment shocks at the state and municipal levels. We call the instrumental variable Usempl and fit the following model at the municipal level:

$$
\begin{aligned}
& \text { (Eq. 1) } \text { Return }_{i, t}=\beta_{1}+\beta_{2} \text { Usempl }_{i, t}+\beta_{3} X_{i, t}+v_{i}+u_{i, t} \\
& \text { (Eq. 2) } \text { Turnout }_{i, t}=\beta_{4}+\beta_{5} \text { Retur }_{i, t}+\beta_{6} X_{i, t}+v_{i}+u_{i, t}
\end{aligned}
$$

In the first regression step, $\operatorname{Return}_{i, t}$ is the share of return migrants in municipality $i$ at time $t$, explained by an increase in the instrument Usempl (changes in unemployment rates over the previous three years in U.S. states where Mexican migrants live) as explained above. $\mathrm{X}$ is a vector of control variables. The $\beta$ are the estimated coefficients, $u$ is the error term, and $v$ is a municipality fixed effect 
that controls for all time-invariant unobserved factors at the level of municipalities. In the second regression step (2), Turnout $_{i, t}$ refers to the election outcome in municipality $i$ at time $t$, and $\widehat{\text { Retur }} n_{\mathrm{i}, \mathrm{t}}$ are the estimates from the first step equation (1). The regressions use data from up to 2,125 municipalities for which data on turnout are available, return migration, and control variables for at least two periods (out of a total of 2,456 municipalities). ${ }^{14}$

The exogeneity of the instrument is satisfied as long as regional variation in U.S. labour market conditions does not have an effect on variation in election outcomes in Mexico other than through the migration channel. There are several potential concerns with respect to instrument exogeneity. First, labour market shocks at destination may affect migratory routes as well as selection into migration (Orrenius and Zavodny 2005; Fajardo, Gutiérrez, and Larreguy 2017). The effect of labour market shocks on migration decisions could therefore be reflected in the requests for consular documents, hence biasing our estimate of exposure to unemployment shocks at destination. In that case, the instrumental variable would partly measure migration responses to changes in unemployment increases at destination rather than the effect of the shock itself. To address this concern, we measure migration corridors as the cumulative count of document requests up to 2008, the year when the U.S. financial crisis affected labour markets (our main exogenous shock). Hence, unemployment shocks in the context of the U.S. financial crisis are excluded from our measure of migration corridors. Also, crime may be a cause of international displacements. The instrumented interaction would be biased if the weights used for creating the instrumental variable are themselves affected by crime in Mexican states. However, the security situation deteriorated around 2008

14 The drop in observations in the estimations for municipal turnout (See Appendix S2) is mostly due to limited data for the state of Oaxaca with its 570 municipalities. Return data for the year 2000 are not available for most of the smaller municipalities of the state of Oaxaca. Moreover, the state of Oaxaca does not hold party-based local elections, but is governed according to local traditions (usos y costumbres). The sample is further reduced due to limited data availability on some covariates. 
or only shortly before (Shirk and Wallman 2015), while the overwhelming number of matrículas were handed out to people who had emigrated before that year. Importantly, municipality fixed effects control for all time-constant characteristics that might be related to patterns of self-selection into either emigration or return migration, including institutional legacies, historical migration patterns, and geographical differences. Hence, the instrument builds entirely on regional variation in labour markets across U.S. states, which is plausibly unrelated to regional variation in electoral participation in Mexico. A second concern is that U.S. unemployment shocks may possibly affect economic conditions in Mexico through channels other than migration that may also be related to turnout during elections; for instance, trade links. If trade occurs along migration routes, this could pose a threat to identification. To account for this, we include a number of state and municipal controls that reflect sub-national economic conditions. Finally, besides return migration, U.S. unemployment shocks affect other migration variables, in particular outmigration, as well as the flow of remittances. These flows have been related to electoral engagement (Bravo 2009; Ebeke and Yogo 2013; Dionne, Inman, and Montinola 2014; Duquette-Rury and Chen 2018). To account for this, we provide regression results that explicitly control for emigration rates and remittances and for indirect socioeconomic outcomes of remittances. This being said, the instrument likely captures other dimensions of migration too. Return migration rates should therefore be understood as an observable measure of a broader migration shock that typically goes hand in hand with lower emigration rates and changes in remittance flows.

A number of additional socioeconomic controls are included in the models, both at the municipal and at the state level. Control variables refer to the years 2000, 2005, and 2010 for which census data and population count data are available. Population $(\log )$ measures municipal population size. An aggregate index of poverty available in the Mexican census (Marginality) combines information on literacy rates, income levels, and social infrastructure in each municipality. Male refers to the share of households headed by males. The age of the household head (Age) serves as an indicator of demographic composition. The variable Indigenous indicates whether an indigenous language was spoken in the household. Education is 
the average number of years of schooling of household heads in the municipality. GDPShare is the respective state's share of Mexican GDP, and GDPPC measures per capita GDP at the Mexican state level. Homicides are annual homicides per 100,000 persons at the level of municipalities. The expectation concerning these variables is that deprivation stifles electoral participation. From Ley (2018) we take two indicators of the competitiveness of elections: the effective number of parties (Enp) and the margin of victory (Margin). We expect that turnout will increase in competitive settings. We also control for the party in power at the state level and the vote share of each of the main parties during presidential elections. ${ }^{15}$ See Table A1 in the Appendix for a description of all variables and sources.

In addition to testing an average effect of return migration on electoral engagement, we explore whether a context of crime further affects rates of political participation in presidential elections. According to our hypothesis, we expect that violence will magnify the negative effect of return migration on electoral turnout. As explained, in the context where distrust toward the political system is the norm, returnees may be even more unmotivated to exert any political leadership, at least as reflected in greater electoral participation. To test this proposition, we interact return migration with the level of violence in municipality $i$ at time $t$, using the interaction between $U$ sempl and indicators of violence as an instrument for the interaction term. We use three alternative variables to measure the presence of crime: a binary variable for the presence of drug cartels in the municipalities (Cartels), the number of cartels in a municipality (Nr. Cartels), and drug-related sentences (Sentenced), all taken from Ríos and Coscia (2012).

${ }^{15}$ For local elections (reported in the Supplementary Appendix Table S2), we control for the vote share of each of the main parties either alone or in coalition during the latest local elections. The variable Last Election counts the number of years since the last municipal election took place, in order to account for variation in election cycles. 
As mentioned, crime rates may not be exogenous to return migration, although the direction of the relationship is debated (Bucheli et al 2019; Blake 2014; Ambrosius and Leblang 2018). If this is the case, the coefficient of the interaction between return migration and crime might be biased. While drug cartels are related to rising crime in Mexico over the period under study, it is unlikely that the rate of return migration had a causal effect on the presence of drug cartels, since the latter has far deeper long term structural and political roots (Pansters 2018). We therefore see endogeneity as less of a concern if we use variables related to the presence of cartels.

\section{Results}

Our results give support to our stated hypothesis: Return migration depresses electoral turnout in presidential elections, and this effect is stronger in high crime contexts. Table 1 shows first and second step results for our main model. Columns (1), (2) and (3) show results from the first regression step (eq. 1) in which we estimate the effect of (changes in) unemployment levels in the U.S. states where Mexican migrants live (Usempl) on return migration. We use these first step results from columns (1) to (3) to estimate second step results on turnout (eq. 2) in presidential elections in columns (4) to (6). Columns (1) and (4) are our baseline regressions for the first and second step. In order to highlight an effect of return migration as distinct from emigration and remittances effects, first step column (3) and second step column (6) include controls for the rates of out-migration (the share of households who reported emigrants over the previous five years) and the share of households who received remittances during the previous 12 months. These variables are available for the years 2000 and 2010 only. To make coefficients comparable, we also show the baseline results without the year 2005 in columns (2) and (4). All results include municipality fixed effects. This allows us to control for all variables that do not change over time (such as geographic differences, institutional legacies and migration histories). Heteroscedastic robust standard errors clustered at the municipal level are in brackets. 
The instrument has the expected sign and is strong: an increase in unemployment rates at destination is associated with more return migration. ${ }^{16}$ In addition, municipalities with a younger population, a higher ratio of households headed by men, a higher share of indigenous populations, and smaller municipalities received a larger number of returnees. Also, poorer states in terms of per capita GDP $(g d p p c)$ and municipalities with a higher effective number of parties (enp) had a higher inflow of returnees.

Our main interest lies in the second step coefficient of return migration in explaining voter turnout during presidential elections (columns (4) and (6)). Both coefficients are large in size and highly statistically significant. In terms of substantive effects, an increase in the share of return migration by one percentage point at the municipal level decreases expected turnout rates by 8 percentage points in presidential elections (column 5) and 11 percentage points when we include controls for emigration and remittances. The positive effect is confirmed (and even increases) when we include remittances and emigration controls. This makes us confident that the result is driven by return migration rather than by changes in remittances or out-migration rates. Appendix Table A2 shows results for the un-instrumented (biased) regression results. The coefficients have the same sign and are statistically significant, but smaller

\footnotetext{
${ }^{16}$ Weak instrument F statistics are above the conventional thresholds of 10 (Stock and Yogo 2002).
} 
in magnitude. ${ }^{17}$ We observe a similar negative relationship between return migration and political participation in municipal elections (see Supplementary Appendix Table S2). ${ }^{18}$

Regarding control variables, most behave as expected. More violence is associated with lower turnout rates, confirming previous findings (Trelles and Carreras 2012a; Ley 2018). A higher age of household heads is associated with lower turnout. In presidential elections, municipalities with lower education and more male-headed households had higher abstention rates. For the most part, worse socioeconomic conditions proxied in different ways correlate with lower turnout on Election Day.

***Table 1: Effect of Return Migration on Voter Turnout, Presidential Elections. Instrumented Results***

We now turn to the heterogeneity of the effect of return migration on electoral turnout. We argued that returning to contexts of violence and crime might affect returnees' alienation and their probability of

${ }^{17}$ Although the exact sources of bias are unknown, one possibility is that worse economic or political contexts are associated with lower turnout rates, but also pose a dis-incentive to return. Some of these - for instance corruption and other abuses of political power, unreported violence or local economies of crime are hard to capture using observable variables at the municipal level. In this case, the true effect of return migration would be underestimated. The fact that the substantive effect using municipal data is similar to that reported in previous research (Duquette-Rury and Chen 2018) reassures us of the validity of our identification strategy.

${ }^{18}$ Our results are robust to removing the controls for electoral competitiveness (Supplementary Appendix Table S1). When we measure turnout in local elections, the effect of return migration on turnout is insignificant in the second step regression once we exclude the year 2005. We attribute this to the difficulty of identifying an effect over a long ten-year period when local elections happen every three years and in a staggered calendar. 
contemplating repeated migration, in turn affecting their willingness to make political investments in their communities. Further, the portrayal of this cohort of returnees as failures as well as a threat, or even a cause of violence makes non-migrant co-nationals unlikely to consider these returnees as carriers of valuable norms. These two mechanisms are not exclusive and are likely to feed on each other. Both predict that the negative effect of return rates on turnout rates will be magnified when violence is rampant. In Table 2, we show the second step results, interacting return migration with different indicators of violence and crime. Column (1) shows the second step results for presidential elections, interacting return migration with the presence of cartels. Column (2) in turn uses the number of cartels present in a municipality rather than the presence of cartels as such, since rivalry between competing cartels has been a key explanation for escalating violence in Mexico (Shirk and Wallman 2015; Rios 2015). Column (3) reports results for an interaction between return migration and the log of drug-related sentences. Due to lack of data, we drop the year 2000 in the interacted regressions. As an instrument for the interactions, we interact the instrument Usempl with each of the three crime variables in the first step regression (see Table $\mathrm{S} 3$ in the Supplementary Appendix for first step results). The positive and statistically significant sign for the interaction terms in Table 2 suggests that as anticipated, a high number of returnees in the municipality adds to political alienation even more when migrants return to a context of crime and violence. ${ }^{19} \mathrm{We}$ observe the same pattern for the case of turnout in municipal elections (see Supplementary Appendix Table S4). Overall, returnees disengage from electoral politics. The large substantive effects that we find in our data suggest that disenchantment with the political system, limited emigration opportunities, and high crime had spillover effects that affected communities' electoral engagement overall.

${ }^{19}$ In line with Appendix Table A2, we observe the same sign but smaller coefficients for interactions that do not use instruments (see Appendix Table A3). 
As an illustration, Figure 1 shows turnout rates predicted from an interaction between rates of return and the presence of cartels (column (1) in Table 2). The negative effect of return migration on abstention rates is heightened in contexts of crime and violence. To provide an example, the municipality of Calvillo in Aguascalientes registered a sizeable increase in the share of return migrants between 2005 and 2010, from 1.3 to 5.3. Also, drug cartels were present in 2012. The predicted turnout rate in presidential elections in Calvillo is about $15 \%$ lower than if there had been no increase in return migration and no presence of cartels (and about $9 \%$ lower had there been the same rate of return but no presence of cartels). ${ }^{20}$

*** Table 2: Conditional Effect of Return Migration on Voter Turnout, Presidential Elections. Instrumented 2nd Step Results ***

*** Figure 1: Effect of Return Migration on Voter Turnout During Presidential Elections, Conditional on the Presence of Cartels ***

\section{Discussion and Further Research}

Research on the political consequences of return migration in origin countries is in its infancy. And the scarce research that does exist is contradictory in its expectations and findings (Rother 2009; Batista and Vicente 2011; Chauvet and Mercier 2014; Pérez-Armendáriz 2014; Duquette-Rury and Chen 2018;

${ }^{20}$ Coefficients from Table 2 are not directly comparable to Table 1 because Table 2 covers the years 2005 and 2010 only, while column (4) in Table 1 includes the year 2000. 
Bucheli, Fontenla, and Waddell 2019). There is an optimistic camp that reports positive effects of return migration on the political life of communities via the transfer of norms and behaviours learned while abroad. However, research has so far overlooked the importance of the circumstances surrounding the act of returning, as well as the socio-political environment returnees encounter once they are back.

We start to unpack the political effects of return migration by making it explicit that context matters. In particular, we look at the return migration that followed the Great Recession and tightened migration and border policies in the U.S. This change in economic and political conditions in destination forced many migrants and their families to go back to their communities of origin, stigmatising their return as a failure (Hazan 2014; Pérez-Armendáriz 2014). Under these adverse circumstances, the necessary climate of trust that is a pre-requisite for social remittances to flow from returnees to their communities is unlikely to be present. Moreover, with security fast deteriorating in parallel, faltering interpersonal trust could only increase returnees' and their communities' perception of political inefficacy. Using a variety of indicators and specifications, we find that return migration is associated with lower participation in federal and local elections in Mexico. We also find that this effect is magnified in violent contexts, with substantive effects on electoral engagement. All in all, we do not find evidence of return migrants acting as drivers of electoral participation.

This research should be expanded and qualified on two fronts. First, we have confined ourselves to exploring the impact of return migration on election turnout, but this is obviously not the only mode of political engagement where returnees may become involved. Indeed, some studies have reported that those with a wide variety of migrant connections tend to disengage from electoral politics, but become more engaged in non-electoral political activities (Pérez-Armendáriz and Crow 2010; Córdova and Hiskey 2015; Ley, Ibarra-Olivo, and Meseguer 2019; Pérez-Armendáriz and Duquette-Rury 2019). While research so far has focused on international connections such as receiving remittances or having emigrant relatives abroad, we claim that return migration might also be causally related with other non-electoral political activities, 
including contentious violent politics. In violent democracies like Mexico, these behaviours may arguably be seen as more effective means of influencing politics than voting in elections.

And second, given the prominence of insecurity in Mexico, we decided to focus on the heterogeneous effects associated with the context of rampant insecurity that has been a feature of our research period; but there are other political and economic factors equally worth exploring, such as connections between return migration and political participation. The quality of sub-national institutions, the nature of political competition, or pre-existing levels of poverty are just some examples of variables worth looking at that might express the relationship between returnees and their role as agents of political and economic change. With increased restrictions on migration around the world, and return migration on the rise, exploring its political consequences in consolidating, often violent, democracies should be a priority for scholars of international migration and political behaviour. 


\section{APPENDIX}

***Table A1: Data Description (Municipality and State Level) ***

***Table A2: Return Migration and Voter Turnout During Presidential Elections. Uninstrumented OLS $* * *$

*** Table A3: Return Migration on Voter Turnout, Conditional on Crime and Violence. Uninstrumented OLS *** 


\section{LITERATURE}

Ambrosius, Christian, and David A. Leblang. 2018. 'Exporting Murder: US Deportations \& the Spread of Violence'. Discussion Paper, School of Business \& Economics: Economics 2018/13. Freie Universität Berlin.

Astorga, Luis, and David A. Shirk. 2010. 'Drug Trafficking Organizations and Counter-Drug Strategies in the U.S.-Mexican Context'. https://escholarship.org/uc/item/8j647429.

Batista, Catia, and Pedro C Vicente. 2011. 'Do Migrants Improve Governance at Home? Evidence from a Voting Experiment'. The World Bank Economic Review 25 (1): 77-104.

BBVA Bancomer. 2015. 'Anuario de Migración y Remesas'.

Blake, Garfield O. 2014. 'America’s Deadly Export: Evidence from Cross-Country Panel Data of Deportation and Homicide Rates'. International Review of Law and Economics 37: 156-168.

Blanco, Luisa R. 2013. 'The Impact of Crime on Trust in Institutions in Mexico'. European Journal of Political Economy 32 (December): 38-55. https://doi.org/10.1016/j.ejpoleco.2013.06.004.

Bravo, Jorge. 2009. “Emigración y Compromiso Político en México.” Politica y Gobierno 1:273-310.

Bucheli, José R., Matías Fontenla, and Benjamin James Waddell. 2019. 'Return Migration and Violence'. World Development 116 (April): 113-24. https://doi.org/10.1016/j.worlddev.2018.12.010.

Calderón, Gabriela, Gustavo Robles, Alberto Díaz-Cayeros, and Beatriz Magaloni. 2015. 'The Beheading of Criminal Organizations and the Dynamics of Violence in Mexico'. Journal of Conflict Resolution 59 (8): 1455-85. https://doi.org/10.1177/0022002715587053.

Campos-Vazquez, Raymundo M., and Jaime Lara. 2012. 'Self-Selection Patterns among Return Migrants: Mexico 1990-2010'. IZA Journal of Migration 1 (1): 8. https://doi.org/10.1186/2193-9039-1-8. 
Careja, Romana, and Patrick Emmenegger. 2012. 'Making Democratic Citizens: The Effects of Migration Experience on Political Attitudes in Central and Eastern Europe'. Comparative Political Studies 45 (1): 871-98.

Cassarino, Jean Pierre. 2004. 'Theorising Return Migration: The Conceptual Approach to Return Migrants Revisited'. International Journal on Multicultural Societies 6 (2): 253-69.

Chauvet, Lisa, and Marion Mercier. 2014. 'Do Return Migrants Transfer Political Norms to Their Origin Country? Evidence from Mali'. Journal of Comparative Economics 42: 630-51.

CIDAC. 2016. Resultados Electorales 1985-2012. http://elecciones.cidac.org/.

Consejo Nacional de Evaluación de la Política de Desarrollo Social (CONEVAL). 2017. 'Indicadores de Pobreza, Pobreza Por Ingresos, Rezago Social y Gini a Nivel Municipal,1990, 2000, 2005 y 2010 ’.

Consejo Nacional de Población (CONAPO). 2002. Índices de Intensidad Migratoria México-Estados Unidos, 2000. México, D.F. 2012. Índices de Intensidad Migratoria México-Estados Unidos, 2010. México, D.F.

Córdova, Abby, and Jonathan Hiskey. 2015. 'Shaping Politics at Home Cross-Border Social Ties and Local-Level Political Engagement'. Comparative Political Studies 48 (11): 1454-87.

Délano, Alexandra. 2012. 'From "Shared Responsibility" to a Migration Agreement? The Limits for Cooperation in the Mexico-United States Case (2000-2008)1'. International Migration 50: e41e50. https://doi.org/10.1111/j.1468-2435.2009.00572.x.

Demirgüç-Kunt, Asl1, Ernesto López Córdova, María Soledad Martinez Pería, and Christopher Woodruff. 2011. 'Remittances and Banking Sector Breadth and Depth. Evidence from Mexico'. Journal of Development Economics 95 (2): 229-41. 
Denier, Nicole, and Claudia Masferrer. 2019. 'Returning to a New Mexican Labor Market? Regional Variation in the Economic Incorporation of Return Migrants from the US to Mexico'. Population Research and Policy Review. https://doi.org/10.1007/s11113-019-09547-w.

Dionne, K.Y., K.L. Inman, and G.R. Montinola. 2014. ‘Another Resource Curse?: The Impact of Remittances on Political Participation'. Afrobarometer Working Paper 145. http://www.eldis.org/go/home\&id=69978\&type=Document\#.VZAlLvlVhHw.

Duquette-Rury, Lauren, and Zhenxiang Chen. 2018. 'Does International Migration Affect Political Participation? Evidence from Multiple Data Sources across Mexican Municipalities, 1990-2013’: International Migration Review, June. https://doi.org/10.1177/0197918318774499.

Durand, Jorge. 2013. 'La “Desmigratización” de La Relación Bilateral: Balance Del Sexenio de Felipe Calderón’. Foro Internacional 53 (3/4 (213-214)): 750-70.

Durand, Jorge, Douglas Massey, and Ernesto Parrado. 1999. 'The New Era of Mexican Migration to the United States'. The Journal of American History 86 (2): 518-536.

Ebeke, Christian, and Thierry Yogo. 2013. 'Remittances and the Voter Turnout in Sub-Saharan Africa: Evidence from Macro and Micro Level Data'. African Development Bank Group, Working Paper Series 185 .

Fajardo, Gustavo, Emilio Gutiérrez, and Horacio Larreguy. 2017. 'Taking One for the Team: Shocks at Destination and Households' Supply of Migrants'. WorkingPaper. CAF. https://scioteca.caf.com/handle/123456789/1082.

Fitzgerald, David S. 2013. 'Emigration's Impacts on Mexico: A Sociology of Dissimilation'. In How Immigrants Impact Their Homelands, 114-37. Durham, NC: Duke University Press. 
García-Zamora, Rodolfo. 2014. ‘Crisis, Nafta, and International Migration'. International Journal of Political Economy 43 (2): 27-46.

Germano, Roy. 2013. 'Migrants' Remittances and Economic Voting in the Mexican Countryside'. Electoral Studies 32 (4): 875-85.

Goodman, Gary L, and Jonathan T Hiskey. 2008. 'Exit without Leaving: Political Disengagement in High Migration Municipalities in Mexico'. Comparative Politics 40 (2): 169-88.

Guerrero, Eduardo. 2010. 'Pandillas and Cárteles: La Gran Alianza'. Nexos, 1 June 2010. https://www.nexos.com.mx/?p=13690.

Hazan, Miryam. 2014. 'Understanding Return Migration to Mexico. Towards a Comprehensive Policy for the Reintegration of Returning Migrants.' Center for Comparative Migration Studies.

Hiskey, Jonathan, Daniel J. Montalvo, and Diana Orcés. 2014. 'Democracy, Governance, and Emigration Intentions in Latin America and the Caribbean'. Studies in Comparative International Development 49 (1): 89-111. https://doi.org/10.1007/s12116-014-9150-6.

Hiskey, Jonathan T, Abby Córdova, Mary Fran Malone, and Diana Orcés. 2018. 'Leaving the Devil You Know: Crime Victimization, US Deterrence Policy, and the Emigration Decision in Central America’ 53 (3): 429-47.

Instituto de los Mexicanos en el Exterior (IME). 2008. 'Matrículas Consulares de Alta Seguridad Expedidas Por Consulado y Estado Mexicano de Procedencia'.

Jiménez, Luis Francisco. 2008. 'De Paisano a Paisano: Mexican Migrants and the Trasnference of Political Attitudes to the Country of Origin'. 
Kapur, Devesh. 2010. Diaspora, Development, and Democracy: The Domestic Impact of International Migration from India. Princeton University Press.

2014. 'Political Effects of International Migration'. Annual Review of Political Science 17: 479502.

Kessler, Christl, and Stefan Rother. 2016. Democratization through Migration? Political Remittances and Participation of Philippine Return Migrants. Lanham: Lexington Books.

Lafleur, Jean-Michel, and Leticia Calderón Chelius. 2011. 'Assessing Emigrant Participation in Home Country Elections: The Case of Mexico’s 2006 Presidential Election'. International Migration 49 (3): 99-124. https://doi.org/10.1111/j.1468-2435.2010.00682.x.

Levitt, Peggy. 1998. 'Social Remittances: Migration Driven Local-Level Forms of Cultural Diffusion'. International Migration Review, 926-48.

Levitt, Peggy, and Deepak Lamba-Nieves. 2011. 'Social Remittances Revisited'. Journal of Ethnic and Migration Studies 37 (1): 1-22. https://doi.org/10.1080/1369183X.2011.521361.

Ley, Sandra. 2018. 'To Vote or Not to Vote: How Criminal Violence Shapes Electoral Participation'. Journal of Conflict Resolution 62 (9): 1963-1990. https://doi.org/10.1177/0022002717708600.

Ley, Sandra, Eduardo Ibarra-Olivo, and Covadonga Meseguer. 2019. 'Vigilantism and Family Remittances'. Journal of Ethnic and Migration Studies. https://doi.org/10.1080/1369183X.2019.1623309.

Ley, Sandra, Shannan Mattiace, and Guillermo Trejo. 2019. 'Indigenous Resistance to Criminal Governance: Why Regional Ethnic Autonomy Institutions Protect Communities from Narco Rule in Mexico'. Latin American Research Review 54 (1): 181-200. 
Li Ng, Juan José, Alfredo Salgado, and Carlos Serrano. 2016. 'Migración de Retorno'. In Migración y Remesas En México 2016, BBVA Bancomer Research, 80-93.

López, Ana Isabel. 2018. 'Economic Remittances, Temporary Migration and Voter Turnout in Mexico'. Migration Studies 6 (1): 20-52. https://doi.org/10.1093/migration/mnx023.

López Córdova, Ernesto. 2005. 'Globalization, Migration and Development: The Role of Mexican Migrant Remittances'. Economia, Journal of the Latin American and Caribbean Economic Association, 217-56.

Martínez, Daniel E., Jeremy Slack, and Ricardo D. Martinez-Schuldt. 2018. “"Unauthorized Permanent Resident": A Quantitative Assessment of Migration Intentions Postdeportation.' International Migration Review 52 (4): 1186-1217.

Masferrer, Claudia, and Bryan R Roberts. 2012. 'Going Back Home? Changing Demography and Geography of Mexican Return Migration'. Population Research and Policy Review 31 (4): 465-96.

Maydom, Barry. 2017. 'Migrant Remittances and Democracy’. University of Oxford. https://ora.ox.ac.uk/objects/uuid:dda7fbac-feaf-439a-a82c-6d93ebdf31b5.

McCann, James A, Wayne A Cornelius, and David Leal. 2009. 'Absentee Voting and Transnational Civic Engagement among Mexican Expatriates'. In Consolidating Mexico’s Democracy, 89-108. Baltimore, Maryland: John Hopkins University Press.

McKenzie, David, and Hillel Rapoport. 2007. 'Network Effects and the Dynamics of Migration and Inequality: Theory and Evidence from Mexico'. Journal of Development Economics 84 (1): 1-24. https://doi.org/10.1016/j.jdeveco.2006.11.003.

Meseguer, Covadonga, and Katrina Burgess. 2014. 'International Migration and Home Country Politics'. Studies in Comparative International Development 49 (1): 1-12. 
Meseguer, Covadonga, Sandra Ley, and Eduardo Ibarra-Olivo. 2017. 'Sending Money Home in Times of Crime'. Journal of Ethnic and Migration Studies. https://doi.org/10.1080/1369183X.2017.1300052.

Moctezuma, Miguel. 2013. 'Retorno de Migrantes a México. Su Reformulación Conceptual.' Papeles de Población 19 (77): 149-75.

Montoya-Ortiz, Merari Stephanie, and Juan Gabino González-Becerril. 2015. 'Evolución de la migración de retorno en México: migrantes procedentes de Estados Unidos en 1995 y de 1999 a 2014 '. Papeles de Población 21 (85): 47-78.

Orozco-Aleman, Sandra, and Heriberto Gonzalez-Lozano. 2018. 'Drug Violence and Migration Flows: Lessons from the Mexican Drug War'. Journal of Human Resources 53 (3): 717-49.

Orrenius, Pia M., and Madeline Zavodny. 2005. ‘Self-Selection among Undocumented Immigrants from Mexico'. Journal of Development Economics 78 (1): 215-240.

Pansters, Wil G. 2018. 'Drug Trafficking, the Informal Ordern, and Caciques. Reflections on the CrimeGovernance Nexus in Mexico'. Global Crime 19 (3-4): 315-38.

Parrado, Emilio A., and Edith Y. Gutiérrez. 2016. 'The Changing Nature of Return Migration to Mexico, 1990-2010. Implications for Labor Market Incorporation and Development Sociology of Development'. Sociology of Development 2 (2): 93-118.

Passel, Jeffrey, D’Vera Cohn, and Ana Gonzalez-Barrera. 2012. 'Net Migration from Mexico Falls to Zero-and Perhaps Less'. Pew Hispanic Center. www.pewhispanic.org.

Pérez-Armendáriz, Clarisa. 2014. 'Cross-Border Discussions and Political Behavior in Migrant-Sending Countries'. Studies in Comparative International Development 49 (1): 67-88. 
2019. 'Migrant Transnationalism in Violent Democracies'. Journal of Ethnic and Migration

Studies. https://doi.org/10.1080/1369183X.2019.1623275.

Pérez-Armendáriz, Clarisa, and David Crow. 2010. "Do Migrants Remit Democracy? International Migration, Political Beliefs, and Behavior in Mexico.” Comparative Political Studies 43 (1):11948.

Pérez-Armendáriz, Clarisa, and Lauren Duquette-Rury. 2019. 'The 3×1 Program for Migrants and Vigilante Groups in Contemporary Mexico'. Journal of Ethnic and Migration Studies 0 (0): 1-20. https://doi.org/10.1080/1369183X.2019.1623345.

Pfutze, Tobias. 2012. 'Does Migration Promote Democratization? Evidence from the Mexican Transition'. Journal of Comparative Economics 40 (2): 159-75. https://doi.org/10.1016/j.jce.2012.01.004.

Rios, Viridiana. 2015. 'How Government Coordination Controlled Organized Crime: The Case of Mexico’s Cocaine Markets'. Journal of Conflict Resolution 59 (8): 1433-54. https://doi.org/10.1177/0022002715587052.

Ríos, Viridiana, and Michele Coscia. 2012. 'Knowing Where and How Criminal Organizations Operate Using Google.' CIKM 12: 1421-1421.

Rother, Stefan. 2009. 'Changed in Migration? Philippine Return Migrants and (Un)Deocratic Remittances'. European Journal of East Asian Studies 8 (2): 245-74.

Scarnato, Jenn Miller. 2019. 'Deportation Meets Development: A Case Study of Return Migration in Guatemala'. Migration and Development 8 (2): 192-206.

Shirk, David, and Joel Wallman. 2015. 'Understanding Mexico's Drug Violence'. Journal of Conflict Resolution 59 (8): 1348-76. https://doi.org/10.1177/0022002715587049. 
Silver, Alexis M. 2018. 'Displaced at "Home": 1.5-Generation Immigrants Navigating Membership after Returning to Mexico'. Ethnicities 18 (2): 208-224. https://doi.org/10.1177/1468796817752560.

Spilimbergo, Antonio. 2009. 'Democracy and Foreign Education'. American Economic Review 99 (1): $528-43$.

Stock, James H., and Motohiro Yogo. 2002. Testing for Weak Instruments in Linear IV Regression. National Bureau of Economic Research Cambridge, Mass., USA. http://www.nber.org/papers/t0284.

Trejo, Guillermo, and Sandra Ley. 2018. 'Why Did Drug Cartels Go to War in Mexico? Subnational Party Alternation, the Breakdown of Criminal Protection, and the Onset of Large-Scale Violence'. Comparative Political Studies 51 (7): 900-937. https://doi.org/10.1177/0010414017720703.

Trelles, Alejandro, and Miguel Carreras. 2012. 'Bullets and Votes: Violence and Electoral Participation in Mexico'. Journal of Politics in Latin America 4 (2): 89-123.

Tuccio, Michele, Jackline Wahba, and Bachir Hamdouch. 2019. 'International Migration as Drivers of Political and Social Change: Evidence from Morocco'. Journal of Population Economics 32: 11711203.

U.S. Bureau of Labor Statistics (USBLS). 2014. 'Online Data Base'. www.bls.gov/data/.

Waddell, Benjamin J, and Matías Fontenla. 2015. 'The Mexican Dream? The Effect of Return Migrants on Hometown Development'. The Social Science Journal 52: 386-96.

Waldinger, Roger, and Thomas Soehl. 2013. 'The Bounded Polity: The Limits to Mexican Emigrant Political Participation'. Social Forces 91 (4): 1239-66. https://doi.org/10.1093/sf/sot048. 
Wals, Sergio C. 2013. 'Made in the USA? Immigrants' Imported Ideology and Political Engagement'. Electoral Studies, Special Symposium: The new research agenda on electoral integrity, 32 (4): 75667. https://doi.org/10.1016/j.electstud.2013.05.032.

Woodruff, Christopher. 2007. 'Mexican Microenterprise Investment and Employment: The Role of Remittances'. INTAL-ITD, Working Paper 26. http://www.microdinero.com/resource/download/nota_relacionada/5327-File2744007045072486d49306.pdf.

Woodruff, Christopher, and Rene Zenteno. 2007. 'Migration Networks and Microenterprises in Mexico'. Journal of Development Economics 82 (2): 509-28. 
TABLES

Table 1: Effect of Return Migration on Voter Turnout, Presidential Elections. Instrumented Regression Results

\begin{tabular}{|c|c|c|c|c|c|c|}
\hline & 1st Step & & & 2nd Step & & \\
\hline & (1) & (2) & (3) & (4) & (5) & (6) \\
\hline & Return Mig & ation & & Turnout & & \\
\hline Usempl & $0.042 * * *$ & $0.034 * * *$ & $0.025 * * *$ & & & \\
\hline Return & 「0.00 & 「0. & [0 & $-0.066 * * *$ & $-0.082 * * *$ & $-0.11 * * *$ \\
\hline Emigration & & & $-0.089 * * *$ & & & $\begin{array}{l}10.0301 \\
-0.01 * * \\
{[0.00411}\end{array}$ \\
\hline Remittances & & & $\begin{array}{l}0.042 * * * \\
\lceil 0.0095\rceil\end{array}$ & & & $\begin{array}{l}0.0042 * \\
\lceil 0.0025\rceil\end{array}$ \\
\hline Age & $\begin{array}{l}-0.023 * * * \\
\lceil 0.0087\rceil\end{array}$ & $\begin{array}{l}-0.023 \\
\lceil 0.015\rceil\end{array}$ & $\begin{array}{l}-0.026 * \\
\Gamma 0.0141\end{array}$ & $\begin{array}{l}-0.0021 \\
\lceil 0.0013\rceil\end{array}$ & $\begin{array}{l}-0.0011 \\
\lceil 0.0029]\end{array}$ & $\begin{array}{l}-0.0021 \\
\lceil 0.0034\rceil\end{array}$ \\
\hline Education & $\begin{array}{l}0.001 \\
\lceil 0.03\rceil\end{array}$ & $\begin{array}{l}0.018 \\
\lceil 0.0441\end{array}$ & $\begin{array}{l}-0.055 \\
\lceil 0.041\end{array}$ & $\begin{array}{l}-0.0083^{*} \\
\lceil 0.0045\rceil\end{array}$ & $\begin{array}{l}-0.0096 \\
\lceil 0.00841\end{array}$ & $\begin{array}{l}-0.017 * \\
\lceil 0.0097\rceil\end{array}$ \\
\hline Enp & $\begin{array}{l}0.097 * * * \\
\lceil 0.029\rceil\end{array}$ & $\begin{array}{l}0.071^{*} \\
\lceil 0.039\rceil\end{array}$ & $\begin{array}{l}0.033 \\
\lceil 0.035\rceil\end{array}$ & $\begin{array}{l}-0.0023 \\
\Gamma 0.0041\rceil\end{array}$ & $\begin{array}{l}-0.012 \\
\lceil 0.0081\rceil\end{array}$ & $\begin{array}{l}-0.014 \\
\lceil 0.00881\end{array}$ \\
\hline$G d p p c$ & $\begin{array}{l}-2.7 \mathrm{e}- \\
{[4.7 \mathrm{e}-06\rceil}\end{array}$ & $\begin{array}{l}-6.00 \mathrm{E}-06 \\
\lceil 5.5 \mathrm{e}-06\rceil\end{array}$ & $\begin{array}{l}-1.1 \mathrm{e}-05^{* *} \\
\lceil 5.2 \mathrm{e}-06\rceil\end{array}$ & $\begin{array}{l}-2.7 \mathrm{e}- \\
{[8.1 \mathrm{e}-07\rceil}\end{array}$ & $\begin{array}{l}-1.30 \mathrm{E}-06 \\
\lceil 1.4 \mathrm{e}-06]\end{array}$ & $\begin{array}{l}-1.90 \mathrm{E}-06 \\
{[1.5 \mathrm{e}-06]}\end{array}$ \\
\hline Gdpshare & $\begin{array}{l}11 * * \\
\lceil 4.6\rceil\end{array}$ & $\begin{array}{l}3.6 \\
\lceil 4.6\rceil\end{array}$ & $\begin{array}{l}10 * * \\
\lceil 4.2\rceil\end{array}$ & $\begin{array}{l}-0.0063 \\
\lceil 0.56\rceil\end{array}$ & $\begin{array}{l}-0.56 \\
\lceil 0.87\rceil\end{array}$ & $\begin{array}{l}0.29 \\
\lceil 0.97\rceil\end{array}$ \\
\hline Homicides (log) & $\begin{array}{l}-0.019 * \\
\lceil 0.01\rceil\end{array}$ & $\begin{array}{l}-0.024 \\
\lceil 0.017\rceil\end{array}$ & $\begin{array}{l}-0.019 \\
\lceil 0.016\rceil\end{array}$ & $\begin{array}{l}-0.0025^{*} \\
\lceil 0.0013\rceil\end{array}$ & $\begin{array}{l}-0.0068 * * \\
\lceil 0.003\rceil\end{array}$ & $\begin{array}{l}-0.0071 * * \\
{[0.0036]}\end{array}$ \\
\hline Indigenous & $\begin{array}{l}0.56^{* *} \\
\lceil 0.23\rceil\end{array}$ & $\begin{array}{l}0.61 * \\
\lceil 0.34\rceil\end{array}$ & $\begin{array}{l}-0.08 \\
\lceil 0.33\rceil\end{array}$ & $\begin{array}{l}0.036 \\
\lceil 0.037\rceil\end{array}$ & $\begin{array}{l}0.099 \\
\lceil 0.067\rceil\end{array}$ & $\begin{array}{l}0.038 \\
\lceil 0.079\rceil\end{array}$ \\
\hline Male & $\begin{array}{l}1.7 * * * \\
\lceil 0.39\rceil\end{array}$ & $\begin{array}{l}2.1 * * * \\
\lceil 0.641\end{array}$ & $\begin{array}{l}0.069 \\
\lceil 0.641\end{array}$ & $\begin{array}{l}0.19 * * * \\
\lceil 0.057\rceil\end{array}$ & $\begin{array}{l}0.29 * * \\
\lceil 0.13\rceil\end{array}$ & $\begin{array}{l}0.11 \\
\lceil 0.14\rceil\end{array}$ \\
\hline Marginality & $\begin{array}{l}-4.7 \mathrm{e}-05^{* *} \\
\lceil 1.9 \mathrm{e}-05\rceil\end{array}$ & $\begin{array}{l}-9 \mathrm{e}-05 * * * \\
\lceil 2.2 \mathrm{e}-05\rceil\end{array}$ & $\begin{array}{l}-6.8 \mathrm{e}- \\
\lceil 2 \mathrm{e}-05\rceil\end{array}$ & $\begin{array}{l}-7.1 \mathrm{e}- \\
{[2.7 \mathrm{e}-06\rceil}\end{array}$ & $\begin{array}{l}-1.4 \mathrm{e}- \\
{[5.2 \mathrm{e}-06]}\end{array}$ & $\begin{array}{l}-1.4 \mathrm{e}- \\
\lceil 6 \mathrm{e}-06\rceil\end{array}$ \\
\hline Mun_Spending & $\begin{array}{l}-0.23 * * * \\
\lceil 0.071\end{array}$ & $\begin{array}{l}-0.97 * * * \\
{[0.096]}\end{array}$ & $\begin{array}{l}-0.77 * * * \\
\lceil 0.093\rceil\end{array}$ & $\begin{array}{l}-0.019 * \\
\lceil 0.011\rceil\end{array}$ & $\begin{array}{l}-0.09 * * * \\
\lceil 0.03\rceil\end{array}$ & $\begin{array}{l}-0.098 * * * \\
{[0.035]}\end{array}$ \\
\hline Margin & $\begin{array}{l}2.20 \mathrm{E}-04 \\
\lceil 0.001]\end{array}$ & $\begin{array}{l}-1.20 \mathrm{E}-03 \\
\lceil 0.0014]\end{array}$ & $\begin{array}{l}-8.10 \mathrm{E}-04 \\
\lceil 0.0013]\end{array}$ & $\begin{array}{l}-8.20 \mathrm{E}-05 \\
\lceil 0.00014]\end{array}$ & $\begin{array}{l}-6.80 \mathrm{E}-06 \\
\Gamma 0.000271\end{array}$ & $\begin{array}{l}3.10 \mathrm{E}-06 \\
\lceil 0.00031\rceil\end{array}$ \\
\hline $\begin{array}{l}\text { Population }(\log ) \\
\text { (year)2005 }\end{array}$ & $\begin{array}{l}-0.59 * * * \\
\lceil 0.13\rceil \\
0.0026 \\
\lceil 0.042\rceil\end{array}$ & $\begin{array}{l}-1.5^{* * * *} \\
\lceil 0.16\rceil\end{array}$ & $\begin{array}{l}-0.84 * * * \\
\lceil 0.13\rceil\end{array}$ & $\begin{array}{l}-0.062 * * \\
\lceil 0.03\rceil \\
-0.05 * * * \\
\lceil 0.0065\rceil\end{array}$ & $\begin{array}{l}-0.14 * * \\
\lceil 0.055\rceil\end{array}$ & $\begin{array}{l}-0.11 * * \\
\lceil 0.056]\end{array}$ \\
\hline (year) 2010 & $\begin{array}{l}1.1 * * * \\
\lceil 0.085\rceil\end{array}$ & $\begin{array}{l}1.3 * * * \\
{[0.11]}\end{array}$ & $\begin{array}{l}1 * * * \\
{[0.1\rceil}\end{array}$ & $\begin{array}{l}0.17 * * * \\
{[0.021]}\end{array}$ & $\begin{array}{l}0.21 * * * \\
{[0.044]}\end{array}$ & $\begin{array}{l}0.21 * * * \\
{[0.052]}\end{array}$ \\
\hline $\begin{array}{l}N \\
\text { years covered }\end{array}$ & $\begin{array}{l}6016 \\
2000 / 2005 \\
/ 2010\end{array}$ & $\begin{array}{l}3854 \\
2000 / 2010\end{array}$ & $\begin{array}{l}3854 \\
2000 / 2010\end{array}$ & $\begin{array}{l}6016 \\
2000 / 2005 / \\
2010\end{array}$ & $\begin{array}{l}3854 \\
2000 / 2010\end{array}$ & $\begin{array}{l}3854 \\
2000 / 2010\end{array}$ \\
\hline $\begin{array}{l}R^{\wedge} 2 \\
\text { adi. } R^{\wedge} 2\end{array}$ & $\begin{array}{l}0.57 \\
0.29\end{array}$ & $\begin{array}{l}0.64 \\
0.14\end{array}$ & $\begin{array}{l}0.7 \\
0.27\end{array}$ & & & \\
\hline $\begin{array}{l}\text { weak instr. F-Stat } \\
\text { F-stat }\end{array}$ & 231.2 & 145.06 & 167.21 & 208.98 & 80.65 & 49.71 \\
\hline
\end{tabular}

Statistical significance levels $10 \%(*), 5 \%(* *)$ and $1 \%(* * *)$. All regressions include municipal and year fixed effects. Heteroscedasticity robust standard errors clustered at the municipal level in squared brackets. Partisanship controls are included for shares of each of the main parties during presidential elections in 2000, 2006 and 2012 and for the party in power at the state level. For details see text and data description. 
Table 2: Conditional Effect of Return Migration on Voter Turnout, Presidential Elections. Instrumented $2^{\text {nd }}$ Step Results

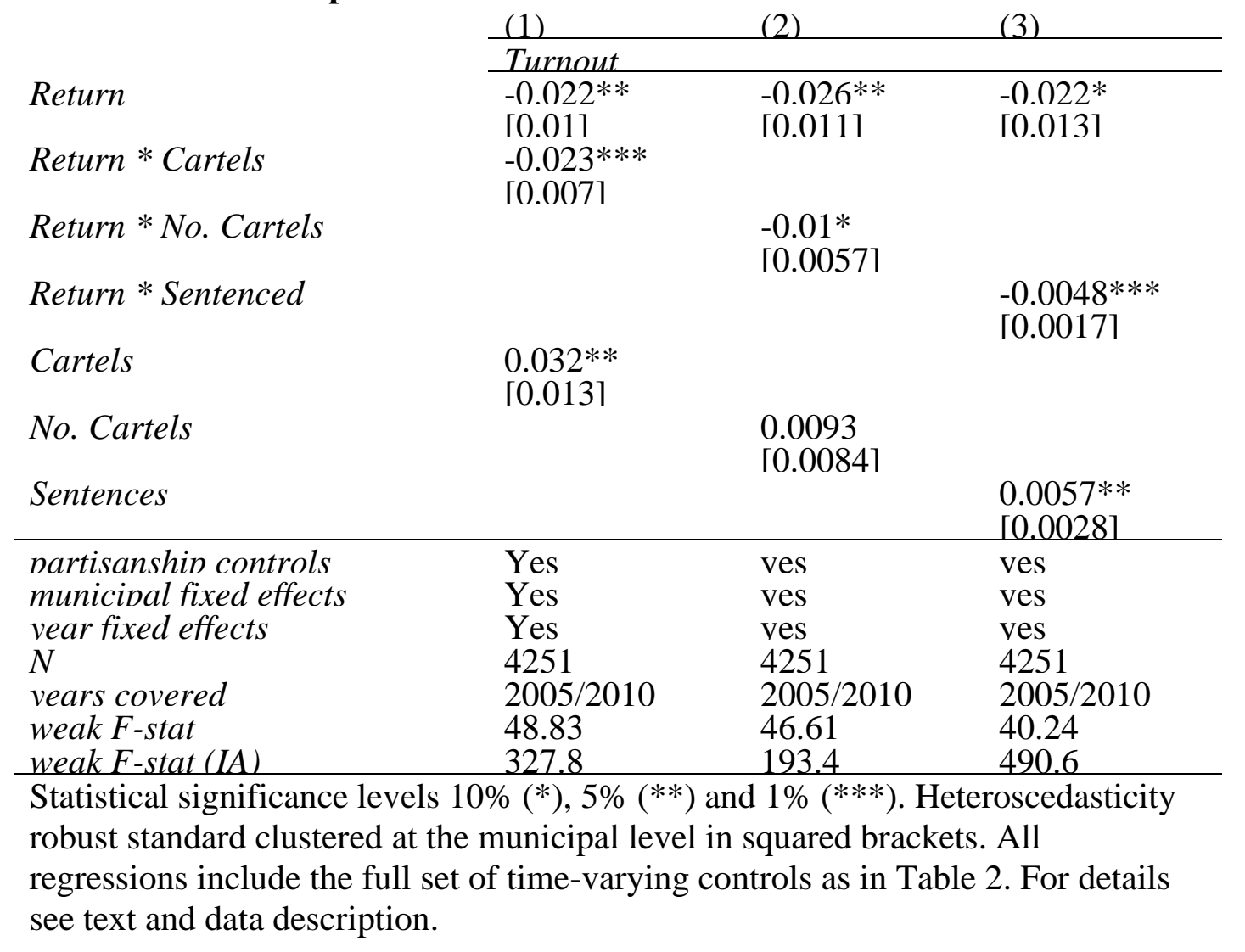


Table A1: Data Description (Municipality and State Level)

\begin{tabular}{|c|c|c|c|c|}
\hline Variable & Description & 2000 & 2005 & 2010 \\
\hline \multirow{2}{*}{$\begin{array}{l}\text { Turnout } \\
\text { (presidential } \\
\text { elections) }\end{array}$} & \multirow{2}{*}{$\begin{array}{l}\text { Voter turnout in presidential elections (2000, } \\
2006,2012)^{\text {a) }}\end{array}$} & 0.6 & 0.56 & 0.65 \\
\hline & & [0.097] & [0.099] & [0.11] \\
\hline \multirow{2}{*}{$\begin{array}{l}\text { Turnout (local } \\
\text { elections) }\end{array}$} & \multirow{2}{*}{$\begin{array}{l}\text { Estimate of voter turnout in most recent } \\
\text { municipal elections (share of total votes relative } \\
\text { to the adult population) }^{\text {b) }}\end{array}$} & 0.66 & 0.66 & 0.67 \\
\hline & & {$[0.16]$} & [0.15] & {$[0.17]$} \\
\hline \multirow[t]{2}{*}{ Return } & \multirow{2}{*}{$\begin{array}{l}\text { Share of the population who returned from abroad } \\
\text { over the previous five years }{ }^{c)}\end{array}$} & 0.51 & 0.4 & 1.5 \\
\hline & & [0.69] & {$[0.56]$} & {$[1.4]$} \\
\hline \multirow[t]{5}{*}{ Usempl } & \multirow{5}{*}{$\begin{array}{l}\text { Indicator of exposure to change in unemployment } \\
\text { rates in US states where Mexican migrants reside. } \\
\text { For each Mexican state } \mathrm{j} \text {, the share of its Diaspora } \\
\mathrm{D} \text { in destination states } \mathrm{k} \text { is multiplied with } \\
\text { changes in unemployment rates } U \text { in state } \mathrm{k} \text { over } \\
\text { the previous three years, and summed up across } \\
\text { all destinations } \mathrm{K} \text { using the formula Usempl } \\
\sum_{\mathrm{k}=1}^{\mathrm{K}} \mathrm{U}_{\mathrm{k}} \mathrm{D}_{\mathrm{k}, \mathrm{j}} \text {. We multiply with historical } \\
\text { migration rates at the level of US states and with } \\
\text { inverse distance to the US border along historical } \\
\text { rail lines to provide different weights at the level } \\
\text { of municipalities (with municipalities closer to } \\
\text { the border via historical rail lines receiving higher } \\
\text { weights). See the data section for a detailed } \\
\text { explanation d) }\end{array}$} & -0.56 & -0.59 & 3.5 \\
\hline & & {$[0.88]$} & [0.91] & [5.5] \\
\hline & & & & \\
\hline & & & & \\
\hline & & & & \\
\hline \multirow[t]{2}{*}{ Age } & \multirow[t]{2}{*}{ Average age of household heads ${ }^{c)}$} & 47 & 48 & 50 \\
\hline & & [3.9] & [4.2] & [3.9] \\
\hline \multirow[t]{2}{*}{ Cartels } & \multirow{2}{*}{$\begin{array}{l}\text { Binary indicator whether drug cartels are } \\
\text { operating in the municipality }(2006,2010)^{\mathrm{g})}\end{array}$} & & 0.12 & 0.29 \\
\hline & & & [0.33] & {$[0.45]$} \\
\hline \multirow[t]{2}{*}{ Cartels No. } & \multirow{2}{*}{$\begin{array}{l}\text { Number of drug cartels operating in the } \\
\text { municipality }(2006,2010)^{g}{ }^{g}\end{array}$} & & 0.2 & 0.61 \\
\hline & & & {$[0.6]$} & [1.2] \\
\hline \multirow[t]{2}{*}{ Education } & \multirow{2}{*}{$\begin{array}{l}\text { Average years of schooling of the head of } \\
\text { household }^{\text {c) }}\end{array}$} & 4.7 & 5.1 & 5.6 \\
\hline & & [1.6] & {$[1.8]$} & {$[1.8]$} \\
\hline \multirow[t]{2}{*}{ Gdppc } & \multirow{2}{*}{$\begin{array}{l}\text { Per capita GDP at the level of Mexican states, in } \\
2005 \text { USD i) }\end{array}$} & 6500 & 5600 & 7100 \\
\hline & & [3200] & [2700] & {$[4500]$} \\
\hline \multirow[t]{2}{*}{$\overline{G d p s h}$} & \multirow[t]{2}{*}{ States' share in Mexican GDP ${ }^{\text {i) }}$} & 0.03 & 0.031 & 0.031 \\
\hline & & {$[0.028]$} & {$[0.027]$} & {$[0.025]$} \\
\hline \multirow{2}{*}{$\begin{array}{l}\text { Homicides } \\
\text { (log) }\end{array}$} & \multirow{2}{*}{$\begin{array}{l}\text { Log of annual homicides per 100,000 inhabitants } \\
\text { i) }\end{array}$} & 1.6 & 1.5 & 1.8 \\
\hline & & [1.6] & [1.5] & [1.7] \\
\hline \multirow[t]{2}{*}{ Indigenous } & \multirow{2}{*}{$\begin{array}{l}\text { Share of persons in the municipality who speak } \\
\text { an indigenous language i) }\end{array}$} & 0.2 & 0.19 & 0.19 \\
\hline & & {$[0.33]$} & [0.32] & {$[0.31]$} \\
\hline \multirow[t]{2}{*}{ Male } & \multirow{2}{*}{$\begin{array}{l}\text { Share of households in the municipality whose } \\
\text { head is male }{ }^{\text {i) }}\end{array}$} & 0.81 & 0.79 & 0.78 \\
\hline & & {$[0.059]$} & {$[0.068]$} & {$[0.055]$} \\
\hline \multirow[t]{2}{*}{ Maginality } & \multirow{2}{*}{$\begin{array}{l}\text { Aggregate indicator of social deprivation } \\
\text { ("rezago social") based on deficiencies in } \\
\text { educational achievements, access to health } \\
\text { services, and living conditions } \mathrm{f} \text { ) }\end{array}$} & -0.0049 & -0.01 & -0.0025 \\
\hline & & [1] & [0.99] & [1] \\
\hline \multirow[t]{2}{*}{ Mun_spending } & \multirow{2}{*}{$\begin{array}{l}\text { Annual per capita expenditures of municipal } \\
\text { governments (in constant } 2010 \text { Mexican Pesos) }\end{array}$} & 1100 & 2200 & 3600 \\
\hline & & & & \\
\hline
\end{tabular}




\begin{tabular}{|c|c|c|c|c|}
\hline $\begin{array}{l}\text { Population } \\
(\text { log) }\end{array}$ & Log of the population size of municipality ${ }^{c)}$ & $\begin{array}{l}9.3 \\
{[1.5]}\end{array}$ & $\begin{array}{l}9.3 \\
{[1.5]}\end{array}$ & $\begin{array}{l}9.4 \\
{[1.6]}\end{array}$ \\
\hline $\begin{array}{l}\text { Sentenced } \\
(\log )\end{array}$ & $\begin{array}{l}\text { Log of drug-related sentences per 100,000 } \\
\text { inhabitants }(2006,2010)^{g)}\end{array}$ & & $\begin{array}{l}0.88 \\
{[1.4]}\end{array}$ & $\begin{array}{l}1.1 \\
{[1.4]}\end{array}$ \\
\hline Emigration & $\begin{array}{l}\text { Share of households reporting emigrants over the } \\
\text { previous five years }{ }^{\text {h) }}\end{array}$ & $\begin{array}{l}6.4 \\
{[6.8]}\end{array}$ & & $\begin{array}{l}3.8 \\
{[4.1]}\end{array}$ \\
\hline Remittances & $\begin{array}{l}\text { Share of households having received international } \\
\text { remittances over the last year }{ }^{\mathrm{h})}\end{array}$ & $\begin{array}{l}6.5 \\
{[7.7]}\end{array}$ & & $\begin{array}{l}6.5 \\
{[7.3]}\end{array}$ \\
\hline Last Election & Years since last municipal election took place $\left.{ }^{b}\right)$ & $\begin{array}{l}0.32 \\
{[0.47]}\end{array}$ & $\begin{array}{l}0.11 \\
{[0.32]}\end{array}$ & $\begin{array}{l}0.55 \\
{[0.5]}\end{array}$ \\
\hline $\begin{array}{l}\text { Enp (pres. } \\
\text { election) }\end{array}$ & $\begin{array}{l}\text { Effective number of parties in latest federal } \\
\text { election }{ }^{\text {e) }}\end{array}$ & $\begin{array}{l}2.4 \\
{[0.44]}\end{array}$ & $\begin{array}{l}2.7 \\
{[0.68]}\end{array}$ & $\begin{array}{l}3 \\
{[0.79]}\end{array}$ \\
\hline $\begin{array}{l}\text { Enp (local } \\
\text { election) }\end{array}$ & $\begin{array}{l}\text { Effective number of parties in latest local election } \\
\text { e) }\end{array}$ & $\begin{array}{l}2.5 \\
{[0.66]}\end{array}$ & $\begin{array}{l}2.7 \\
{[0.74]}\end{array}$ & $\begin{array}{l}2.8 \\
{[0.79]}\end{array}$ \\
\hline $\begin{array}{l}\text { Margin (local } \\
\text { election) }\end{array}$ & Margin of victory in latest local election ${ }^{\mathrm{e})}$ & $\begin{array}{l}23 \\
{[19]}\end{array}$ & $\begin{array}{l}22 \\
{[17]}\end{array}$ & $\begin{array}{l}20 \\
{[16]}\end{array}$ \\
\hline $\begin{array}{l}\text { Margin (pres. } \\
\text { election) }\end{array}$ & $\begin{array}{l}\text { Margin of victory in presidential elections (2000, } \\
2006,2012) \text { e) }\end{array}$ & $\begin{array}{l}18 \\
{[18]}\end{array}$ & $\begin{array}{l}12 \\
{[11]}\end{array}$ & $\begin{array}{l}12 \\
{[12]}\end{array}$ \\
\hline $\begin{array}{l}\text { PAN (pres. } \\
\text { election) }\end{array}$ & $\begin{array}{l}\text { Share of votes for PAN in federal elections ( } 2000 \text {, } \\
2006,2012)^{\text {a) }}\end{array}$ & $\begin{array}{l}0.27 \\
{[0.16]}\end{array}$ & $\begin{array}{l}0.28 \\
{[0.15]}\end{array}$ & $\begin{array}{l}0.24 \\
{[0.12]}\end{array}$ \\
\hline PAN (state) & $\begin{array}{l}\text { Binary indicator whether state was governed by } \\
\text { PAN }{ }^{\text {b) }}\end{array}$ & $\begin{array}{l}0.17 \\
{[0.38]}\end{array}$ & $\begin{array}{l}0.21 \\
{[0.41]}\end{array}$ & $\begin{array}{l}0.44 \\
{[0.5]}\end{array}$ \\
\hline $\begin{array}{l}\text { PAN (local } \\
\text { election) }\end{array}$ & $\begin{array}{l}\text { Shares of votes for PAN during the most recent } \\
\text { municipal election (either alone or as coalition) }\end{array}$ & $\begin{array}{l}0.22 \\
{[0.18]}\end{array}$ & $\begin{array}{l}0.28 \\
{[0.18]}\end{array}$ & $\begin{array}{l}0.33 \\
{[0.18]}\end{array}$ \\
\hline $\begin{array}{l}\text { PRD (pres. } \\
\text { election) }\end{array}$ & $\begin{array}{l}\text { Share of votes for PRD in federal elections (2000, } \\
2006,2012)^{\text {a) }}\end{array}$ & $\begin{array}{l}0.2 \\
{[0.14]}\end{array}$ & $\begin{array}{l}0.34 \\
{[0.16]}\end{array}$ & $\begin{array}{l}0.2 \\
{[0.12]}\end{array}$ \\
\hline PRD (state) & $\begin{array}{l}\text { Binary indicator whether state was governed by } \\
\text { PRD }{ }^{\text {b) }}\end{array}$ & $\begin{array}{l}0.085 \\
{[0.28]}\end{array}$ & $\begin{array}{l}0.16 \\
{[0.37]}\end{array}$ & $\begin{array}{l}0.49 \\
{[0.5]}\end{array}$ \\
\hline $\begin{array}{l}\text { PRD (local } \\
\text { election) }\end{array}$ & $\begin{array}{l}\text { Shares of votes for PRD during the most recent } \\
\text { municipal election (either alone or as coalition) }\end{array}$ & $\begin{array}{l}0.2 \\
{[0.17]}\end{array}$ & $\begin{array}{l}0.21 \\
{[0.18]}\end{array}$ & $\begin{array}{l}0.19 \\
{[0.18]}\end{array}$ \\
\hline $\begin{array}{l}\text { PRI (pres. } \\
\text { election) }\end{array}$ & $\begin{array}{l}\text { Share of votes for PRI in federal elections (2000, } \\
2006,2012)^{\text {a) }}\end{array}$ & $\begin{array}{l}0.48 \\
{[0.14]}\end{array}$ & $\begin{array}{l}0.32 \\
{[0.12]}\end{array}$ & $\begin{array}{l}0.4 \\
{[0.11]}\end{array}$ \\
\hline PRI (state) & $\begin{array}{l}\text { Binary indicator whether state was governed by } \\
\text { PRI }^{\text {b) }}\end{array}$ & $\begin{array}{l}0.8 \\
{[0.4]}\end{array}$ & $\begin{array}{l}0.53 \\
{[0.5]}\end{array}$ & $\begin{array}{l}0.35 \\
{[0.48]}\end{array}$ \\
\hline $\begin{array}{l}\text { PRI (local } \\
\text { election) }\end{array}$ & $\begin{array}{l}\text { Shares of votes for PRI during the most recent } \\
\text { municipal election (either alone or as coalition) }\end{array}$ & $\begin{array}{l}0.47 \\
{[0.15]}\end{array}$ & $\begin{array}{l}0.43 \\
{[0.13]}\end{array}$ & $\begin{array}{l}0.39 \\
{[0.18]}\end{array}$ \\
\hline
\end{tabular}

The table reports mean values, standard deviations in square brackets for up to 2443 municipalities. Sources: a) Instituto Nacional Electoral (INE), b) CIDAC (2016), c) INEGI data based on 2000 and 2010 censuses and 2005 population count, d) USBLS (2014), IME (2008) and Demirguc-Kunt et al. (2011), e) Ley (2018), f) CONEVAL (2017), g) Ríos_and Coscia 2012, h) CONAPO (2002; 2012) i) INEGI, Sistema Estatal y Municipal de Bases de Datos SIMBAD (URL:

http://sc.inegi.org.mx/cobdem/). 
Table A2: Return Migration and Voter Turnout During Presidential Elections. Uninstrumented OLS

\begin{tabular}{llll}
\hline & $(1)$ & $(2)$ & $(3)$ \\
\hline \multirow{4}{*}{ Return } & Turnout (pres.) & & \\
\cline { 2 - 4 } & $-0.0034^{* * *}$ & $-0.0046^{* *}$ & $-0.0043^{*}$ \\
Emigration & {$[0.0012]$} & {$[0.0021]$} & {$[0.0025]$} \\
& & & 0.00019 \\
Remittances & & {$[6 \mathrm{e}-04]$} \\
& & & -0.00013 \\
\hline time-varying controls & yes & & {$[0.00061]$} \\
municipal fixed effects & yes & yes & yes \\
year fixed effects & yes & yes & yes \\
$N$ & 6019 & yes & yes \\
years covered & $2000 / 20005 / 2010$ & 3857 & 3857 \\
$R^{\wedge} 2$ & 0.47 & $2000 / 2010$ & $2000 / 2010$ \\
$F$-stat & 155.38 & 0.37 & 0.37 \\
\hline Statictica & 47.56 & 43.19 \\
\hline
\end{tabular}

Statistical significance levels $10 \%(*), 5 \%(* *)$ and $1 \%(* * *)$. Heteroscedasticity robust standard errors clustered at the municipal level in squared brackets.

Heteroscedasticity robust standard in squared brackets. Turnout refers to presidential elections held in 2000, 2006 and 2012. All regressions include the full set of timevarying controls as in Table 1. For details see text and data description. For details see text and data description. 
Table A3: Return Migration on Voter Turnout, Conditional on Crime and Violence. Uninstrumented OLS

\begin{tabular}{|c|c|c|c|}
\hline \multirow[b]{2}{*}{ Return } & \multicolumn{3}{|c|}{ Turnout (pres.) } \\
\hline & 0.001 & -0.00041 & 0.0018 \\
\hline & {$[0.0013]$} & {$[0.0013]$} & {$[0.0014]$} \\
\hline \multirow{2}{*}{ Return $*$ Cartels } & $-0.0048 * * *$ & & \\
\hline & {$[0.0018]$} & & \\
\hline \multirow{2}{*}{ Return $* N r$. Cartels } & & -0.00042 & \\
\hline & & {$[0.00091]$} & \\
\hline \multirow[t]{2}{*}{ Return * Sentenced } & & & $-0.002 * * *$ \\
\hline & & & {$[0.00054]$} \\
\hline \multirow[t]{2}{*}{ Cartels } & 0.0036 & & \\
\hline & {$[0.0049]$} & & \\
\hline \multirow[t]{2}{*}{ Nr. Cartels } & & $-0.0046^{* *}$ & \\
\hline & & {$[0.002]$} & \\
\hline \multirow[t]{2}{*}{ Sentences } & & & $0.0028 * *$ \\
\hline & & & {$[0.0013]$} \\
\hline partisanship controls & yes & yes & yes \\
\hline municipal fixed effects & yes & yes & yes \\
\hline year fixed effects & yes & yes & yes \\
\hline$N$ & 4254 & 4254 & 4254 \\
\hline years covered & $2000 / 2010$ & $2000 / 2005 / 2010$ & $2000 / 2010$ \\
\hline$R^{\wedge} 2$ & 0.7 & 0.7 & 0.7 \\
\hline$F$-stat & 205.46 & 206.41 & 206.3 \\
\hline
\end{tabular}

Statistical significance levels $10 \%(*), 5 \%(* *)$ and $1 \%(* * *)$.

Heteroscedasticity robust standard errors clustered at the municipal level in squared brackets. Turnout refers to presidential elections held in 2000, 2006 and 2012. All regressions include the full set of time-varying controls as in Table 1.

For details see text and data description. 